\title{
The impact physical distancing during the COVID-19 pandemic on mental health among adolescents: a systematic literature review
}

\author{
Isma Faridatus Sholihah, Ira Nurmala, Muji Sulistyowati, Shrimarti Rukmini Devy \\ Department EBIOP, Faculty of Public Health, Universitas Airlangga, Surabaya, Indonesia
}

\begin{abstract}
Article Info
Article history:

Received Jul 7, 2021

Revised Nov 5, 2021

Accepted Nov 14, 2021

Keywords:

Adolescents

COVID-19

Mental health

Physical distancing

Social network

Social support

Good health

ABSTRACT

The spread of the coronavirus disesase 2019 (COVID-19) virus is relatively fast and has infected hundreds of countries. The number of people suffering from COVID-19 continues to increase and is increasingly concerning. To reduce the possibility of spreading the Coronavirus, which is easily contagious, the World Health Organization (WHO) advises the public to maintain a safe distance from other people through physical distancing. This study is a systematic review using the preferred reporting item for systematic reviews and meta-analyzes (PRISMA) method using 454 articles from online journal databases. The databases used in the literature search were Pubmed, Science Direct, Sage, Emerald, and Proquest from 2020-2021. Based on the inclusion and exclusion characteristics, there were 8 of 454 articles met the inclusion criteria, and select for in-depth analysis. Physical distancing policy has an impact on adolescent mental health. Some of the mental disorders experienced by adolescents include feeling lonely, anxious, stressed, psychiatric disorders, to emotional disturbances. Boys have a higher increase in mental health problems than girls. We need a social network and social support specifically in adolescents to maintain physical distancing during the adolescent mental health policy in the COVID-19.
\end{abstract}

This is an open access article under the CC BY-SA license.

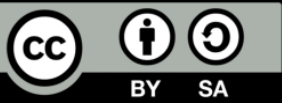

\section{Corresponding Author:}

Ira Nurmala

Department EBIOP, Faculty of Public Health, Universitas Airlangga

Jalan Dr. Ir. H. Soekarno, Mulyorejo, Surabaya, Eact Java, 60115, Indonesia

Email: iranurmala@fkm.unair.ac.id

\section{INTRODUCTION}

The coronavirus disease 2019 (COVID-19) virus is a new virus related to the same virus family as Severe Acute Respiratory Syndrome (SARS) and several common cold viruses. COVID-19 is an infectious disease caused by the acute respiratory syndrome coronavirus 2 (Sars-CoV-2). The disease was first discovered in December 2019 in Wuhan, the capital of China's Hubei Province, and has since spread globally around the world, resulting in the 2019-2020 coronavirus pandemic [1]. The spread of the new Coronavirus is relatively fast and has infected hundreds of countries [2].

Each country has carried out various policies that confirm COVID-19 in their country, from closing airports to imposing restrictions on the movement of their citizens. The number of people suffering from Coronavirus infection or COVID-19 continues to increase and is increasingly concerning [3]. To reduce the possibility of spreading the Coronavirus, which is easily contagious, the World Health Organization (WHO) advises the public to maintain a safe distance from other people through physical distancing. Physical distancing is an effort made to control the spread of coronavirus infection and prevent COVID-19 [4]. 
The physical distancing policy is one of the efforts to prevent the spread of the COVID-19 virus [5], [6]. With this policy keeping most businesses, schools, and universities closed, countries impose travel restrictions [7]. People were encouraged to stay at home and restrictions on contact and even curfew. The COVID-19 pandemic has profoundly affected our lives. The act of regulation imposes a complete change on our psychosocial environment [8]. The benefits of physical distancing, especially during the COVID-19 outbreak, cannot be doubted. However, there is also an impact on mental health that tends to be negative [9].

A person's response to an epidemic/pandemic can vary from one person to person. Croll et al. stated that respondents experienced increased fear (79\%), anxiety (83\%), and depression (38\%) during the COVID-19 pandemic [10]. The physical distancing policy causes teens to miss some of the big moments in their lives and everyday moments, such as chatting with friends and participating in school. At first, maybe some teenagers feel this is their chance for a vacation. Over time the impact of the pandemic turned out to affect the mentality of teenagers [11], [12]. The reason is, some of these teenagers may miss the moments they have been waiting for, such as watching a school art performance or just meeting up with friends [13]. Not a few teenagers are feeling anxious and wonder when this pandemic will end, and everything will return to normal. The study on 555 undergraduate students in China found that anxiety and depression were common predictors of increased negative affect, anxiety, and depression across the confinement period. Students were advised to stay at home to prevent infection and transmission. Students perceived restriction, uncertainty towards the disease, and boredom [14].

Although some teenagers fill their emptiness and anxiety by playing with cellphones or social media, it turns out that this is not enough. According to experts, even though we live where everything relies on technology, humans' still need physical contact and touch with each other. So, reducing social interactions can cause us to feel lonely. The physical distancing policy ultimately makes teenagers stressed and has poor mental health conditions due to lack of interaction [15]. The purpose of this study is to determine the impact of physical distancing during the COVID-19 pandemic, and finding the case on mental health among adolescents during a pandemic helps us to take preventive measures and also increase awareness of the mental health of adolescents during physical distancing policies.

\section{RESEARCH METHOD}

\subsection{Data sources and search strategy}

This research is a systematic review conducted in March 2021. Authors chose relevant studies published from 2020 to 2021 by searching Pubmed, Science Direct, Sage, Emerald, and Proquest with a total of 454 articles found. This systematic review followed the preferred reporting item for systematic reviews and meta-analyzes (PRISMA) guidelines [16]. The literature search process uses research boundaries, and the titles of each database are select according to the patient problem, intervention, comparison or control and outcome (PICO) framework [17]. Research sources used were Pubmed, Science Direct, Sage, Emerald, and Proquest. The keywords used in article searches are physical distancing policies, and mental health, and adolescents.

\subsection{Selection criteria}

Scientific article search was limited with inclusion criteria of online published articles were: i) written in English and published in the years 2020-2021, ii) articles that with full-text of scientific review and original research, iii) the requirements apply to journals with open access, iv) All journals that have been download are reviewed and selected to determine the relationship between physical distancing policies and mental health in adolescents. Articles that do not have an association will be eliminated and not used.

\subsection{Data extraction}

In the final, systematic literature review (SLR), eight journal articles studied the impact of physical distancing policies against adolescent mental health. Figure 1 shows the journal identification process using the PRISMA method. i) Identification: The first step to finding articles is entering the address http://pubmed.ncbi.nlm.nih.gov/ for PubMed, https://www.sciencedirect.com/ for the Science Direct site, https://us.sagepub.com/en-us/nam/journals for Sage sites, https://www.emerald.com/insight/ for Emerald site, and open the address https://www.proquest.com/ for the Proquest site. Then at each site address, enter keywords into search engines. In the filter section, check the full text only option, research article, with the 2020-2021 publication timeframe in determining the type of article the same as on each site. The keywords used in article searches are Physical distancing policies, and Mental Health, and Adolescents. ii) Screening: duplicate articles that appear several times are not reusing, then articles with titles relevant to the research theme are then read the abstract and reviewed according to inclusion criteria. The inclusion criteria in this 
study are original articles that discuss physical distancing policies and Mental Health on adolescents, written in English and published in the years 2020-2021. Abstracts that did not meet the inclusion criteria were eliminating. iii) Eligibility: articles that meet the inclusion criteria are downloading in full text. The requirements apply to journals with open access. All journals that have been download are reviewed and selected to determine the relationship between physical distancing policies and Mental Health in adolescents. Articles that do not have an association will be eliminated and not used. iv) Included: at this stage, articles that meet the inclusion criteria are arranged by author, year of publication, sample, and results.

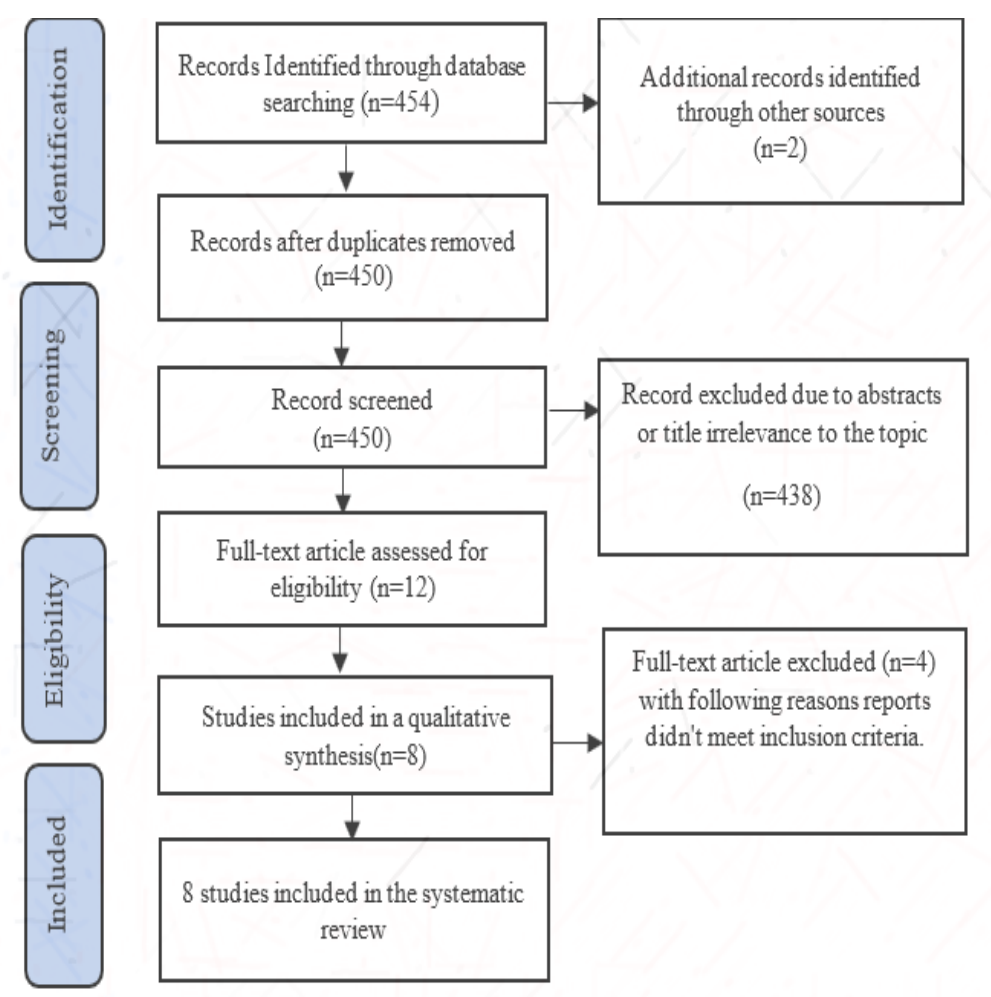

Figure 1. Literature search following the PRISMA diagram

\section{RESULTS AND DISCUSSION}

In the final result, systematic literature review (SLR), eight journal articles studied the impact of physical distancing policies against adolescent mental health. Figure 1 shows the journal identification process using the preferred reporting item for systematic reviews and meta-analyzes (PRISMA) method. A review of the online journal database found 454 articles, of which four exclude due to duplication. A total of 450 review articles with titles and abstracts and 438 articles exclude because they did not meet the inclusion criteria. Furthermore, 12 articles review in full text and four articles were excluded from the study because they did not meet the inclusion criteria. And finally, eight articles meet the requirements and are relevant to current research.

Table 1 shows the characteristics of the articles that qualify for a systematic review. All articles written in 2020-2021 are the research results related to the impact of physical distancing policies on adolescent mental health using adolescent respondents aged 13-22 years. And the research results pertaining were conducted in seven countries such as Bangladesh, Belgium, Swiss, America, Australia, Ireland, and Italy.

Table 2 shows the determinants of mental problems during Physical Distancing which is the cause of adolescent mental health problems as long as the physical distancing policy is applied. Many things trigger the mental health of adolescents during the guarding distance policy. The determinants range from social networking, lack of privacy, digital exclusion, academic stress, institutional dissatisfaction, fear of being infected, physical activity, and dietary behaviors that must change during the physical distancing policy. Table 3 shows the case of mental problem during physical distancing. Table 3 reveals mental problems during physical distancing where the most mental problems experienced by adolescents are depression, anxiety, stress, loneliness. 
Tabel 1. Eligible articles characteristic

\begin{tabular}{cccc}
\hline Author & Country study & Sample size & Age \\
\hline$[18]$ & Bangladesh & 4,800 & $10-22$ \\
{$[19]$} & Belgium & 18,301 & 18 \\
{$[20]$} & Swiss & 212 & 20 \\
{$[21]$} & Bangladesh & 552 & $11-17$ \\
{$[22]$} & Australia & 582 & $13-19$ \\
{$[23]$} & America & 683 & $13-18$ \\
{$[15]$} & Ireland & 109 & $13-18$ \\
{$[24]$} & Italy & 20 & $15-17$ \\
\hline
\end{tabular}

Table 2 Determinants of mental problem during physical distancing

\begin{tabular}{cc}
\hline Author & Determinants of mental problem during physical distancing \\
\hline$[18]$ & Social isolation, lack of privacy, and digital exclusion \\
{$[19]$} & Academic stress, institutional dissatisfaction, and fear of being infected \\
{$[20]$} & Social networks (interaction, friendship, social support, co-studying) \\
{$[21]$} & Physical activity, dietary behaviors \\
{$[22]$} & Physical activity, dietary behaviors, and well-being \\
{$[23]$} & Motivations \\
{$[15]$} & Physical activity, dietary behaviors \\
{$[24]$} & Social isolation and social support \\
\hline
\end{tabular}

Tabel 3 Case of mental problem during physical distancing

\begin{tabular}{ccccc}
\hline Author & Case of mental problem during physical distancing & $\mathrm{n}$ & $\%$ & Duration of physical distancing \\
\hline$[18]$ & Loneliness & 3,830 & $79.80 \%$ & Seven months \\
{$[19]$} & Stress, depression & 13,015 & $71.12 \%$ & Six months \\
{$[20]$} & 208 & $98.11 \%$ & Five months \\
{$[21]$} & Emotional disorder, conduct disorder, hyperactivity & 372 & $67.39 \%$ & Eight months \\
{$[22]$} & Loneliness & 477 & $81.96 \%$ & Five months \\
& Felt sad & 375 & $64.43 \%$ & \\
{$[23]$} & Eating junk food & 454 & $78.00 \%$ & \\
{$[15]$} & Difficulty falling asleep & 341 & $58.59 \%$ & Three months \\
{$[24]$} & Motivation, depression, anxiety & 670 & $98.09 \%$ & Six months \\
\hline
\end{tabular}

\subsection{The determinants that cause mental health problems in adolescents}

Adaptation to changes in habits becomes a new challenge. Not a few people have difficulty adapting to this condition. Appeals to the public to carry out physical distancing help break the chain of COVID-19 transmission [4]. Limiting interactions in a relatively long period is by doing activities at home during an uncertain situation without realizing it affects mental health. Anxiety, worry, anxiety, and frustration often arise when faced with cases full of uncertainty [25], [26]. Other reactions that often occur are anger, boredom, and loneliness. Besides, there is also concern about taking good care of the family, both children and parents. Based on the research that has done, that physical distancing policies impact adolescents' mental health [15], [18], [20]-[23], [27].

The determinants that cause mental health problems in adolescents during the application of physical distancing vary widely. These determinants start from social networking, lack of privacy, digital exclusion, academic stress, institutional dissatisfaction, fear of being infected. The result of the physical distancing policies also causes changes in physical activity and dietary behavior in adolescents. These changes caused mental problems for teenagers during the COVID-19 pandemic. Teenagers have problems psychology related to psychological distress and social dysfunction such as feeling unable to concentrate, feeling under pressure, and less able to enjoy daily activities day [11]. The social interactions that restricted shorten the number of activities daily children's day-child and teenagers. The thing that education already available to realize the schedule study them, most of the schools change class face to face to a meeting online [28]. Many consequences faced by children-child and teens who lost access to school and teacher tall. There is physical health and broad mentality for children and teenagers such as lack of sleep, poor diet, behavior improvement, and change fitness physical also wearing on mental health during COVID pandemic [29].

Academic stress feel in adolescents under policies of physical distancing [19], [30], [31]. Stress due to academic stress is a condition where there is a mismatch between the demands of the environment and the existing resources possessed by students [32]. The various schools increasingly burden them such as academic pressures and demands [33]. Stress is a result of a wide range of issues, including test and exam 
burden, a demanding course, a different educational system, and thinking about future plans upon graduation [34]. A study conducted by O'Sullivan et al. [15] also mentioned the same thing: adolescents under policies physical distancing experience academic stress and depression due to the implementation of home-schooling.

Although studying at home, teenagers cannot live in peace because they have to face the assignments given by the teacher [35]. Time at home spent doing piling up chores. Teachers give lessons so that students still get grades and learning material. The pandemic situation we have experienced shows widespread diversity in the mental health of individuals. How will it affect the adolescent brain in adulthood, particularly the critical areas related to action-emotion regulation (impulsive behavior), empathy, and decision-making skills in adolescents [36]. In times of pandemic, there is an urgent need to reduce the impact experienced by the young population. The more vulnerable ones suffer from social inequalities in which families with low income cannot face education, remote learning, and virtual contact with peers and family members [37]. Educators, administrators, and policymakers must minimize the distraction that school closures will cause to academic development. Schools offer many other essential services to students outside of education. For example, schools are a significant source of nutrition for many students, ensuring food security has become a standard school closure plan. However, other services are just as crucial for children's health [38].

In terms of dietary behavior, adolescents during quarantine and physical distancing during the COVID-19 pandemic increase consumption of junk food or unhealthy food that is at risk of triggering various metabolic diseases. Psychological stresses during the pandemic trigger people to eat these unhealthy foods. A study conducted by Cuhaci et al. revealed that frequent consumption of junk food causes an increase in the production of the hormones testosterone and estrogen, which can cause problems, including stress triggers [39].

\subsection{The case of mental problem during physical distancing}

Adolescents who undergo physical distancing feel the adverse effects, namely feelings of loneliness in adolescents [18]. Loneliness is an individual emotional, and cognitive reaction to a condition where the person concerned only has or undergoes a few relationships or social interactions that are not by his expectations or desires. Or in other words, there are negative feelings that arise in response to the occurrence or loss or reduction of social interactions and the quality of relationships that individuals have due to external, subjective factors [40]. Feelings of loneliness in adolescents during physical policy distancing are also in line with Elmer et al. [20] and Munasinghe et al. [22].

The limitation of distance which makes limited interactions between adolescents, makes adolescents experience anxiety to stress [41]. In a study conducted by Elmer et al. [20], Oosterhoff et al. [23], and Pietrabissa et al. [24] revealed that most teenagers experience period anxiety physical distancing. A person with anxiety disorder can feel a sudden panic attack or anxiety without anything triggering it, and it can be very annoying [42]. If treatment has not done immediately, this disorder can limit a person's ability to work, relate to other people, and relationships with family [43]. As expected, the saddest problem for teenagers during physical distancing policies so far is not meeting their friends, being followed by friends or family members who have contracted and become very sick or died from COVID-19. Also of primary concern to adolescents is the inability to participate in their normal extracurricular activities (for example, sports, dance, and music lessons) or attend social events [44], [45]. Instead, they reported very little concern about catching, getting sick, or dying because of COVID-19.

Other findings in the study by Mallik et al. [21] show that after the physical distancing policy, the prevalence of psychiatric disorders increases to men than women. The mental disorders felt were emotional disorder, conduct disorder, hyperactivity, as much as $67.39 \%$. The study also states that male adolescents are more likely to experience mental health problems during physical distancing policies than adolescent girls. Therefore, particular interventions are needed, both counseling and mentoring for adolescents who are vulnerable to the risk of mental disorders not to worsen their health conditions.

Findings obtained in the study of Munasinghe et al. [22] adolescents experienced a change in behavior, where $78 \%$ of adolescents experienced an increase in junk food consumption and difficulty falling or staying asleep during the physical distancing period. As we all know, junk food is a low-nutrient food often associated with health risks to the body. Not only physical health but consumption of low-nutrient foods is also closely related to mental health. Excessive consumption of junk food has a significant positive relationship with mental health in adolescents [46].

Mental health problems can adversely affect our physical health [47], [48]. Therefore, we have to maintain mental health during a pandemic, COVID-19. The (2019-nCoV) illness perception developed mental disorders, including anxiety and depression, which hasdeclined individuals' mental health. There is an urgent need for ongoing clinical examination and management to address psychological disorders, and findings suggest assessing mental health to combatting the pandemic worldwide [49]. In a study conducted by Munasinghe et al. [22] adolescent mental health worsens during physical distancing policy. One of the

The impact physical distancing during the COVID-19 pandemic on mental ... (Isma Faridatus Sholihah) 
factors supporting that adolescent mental health remains good is the connectedness with friends, family, and school. However, with the physical distancing policy, adolescents must limit themselves by keeping a distance from the people around them, reducing their psychological well-being. According to Elmer et al. [20] one of the crucial factors that can improve adolescent mental health during physical distancing policies is social networking and social support additional stress factors [32], [50]. One social network and social support that can apply in digital form is from study groups, mentoring, and psychological counseling [30]. The mental health of adolescents is well maintained.

\section{CONCLUSION}

Based on the above discussion, the policy of physical distancing impacts adolescent mental health. Some of the mental disorders experienced by adolescents include feeling lonely, anxious, stressed, psychiatric disorders, to emotional disturbances. Boys have a higher mental health disorder than girls. Finding the correct information from trusted sources, reducing social media play, and limiting watching/viewing news about the COVID-19 can also reduce the anxiety felt in adolescents. As much as possible, parents can be friends to share with teenagers. Give space for teens to open up about their uneasy feelings to their parents. Not talking about the COVID-19 too often or looking for a diversion with fun activities and productive things reduces anxiety and makes teenagers feel less burdened. Let teens contact friends to establish communication, share stories and be able to vent their feelings. That way, teenage saturation during the pandemic can be released.

\section{ACKNOWLEDGEMENTS}

Thanks to Universitas Airlangga for providing support so that this article can be published.

\section{REFERENCES}

[1] W. C. Koh, L. Naing, and J. Wong, "Estimating the impact of physical distancing measures in containing COVID-19: An empirical analysis," Int. J. Infect. Dis., vol. 100, pp. 42-49, 2020, doi: 10.1016/j.ijid.2020.08.026.

[2] World Health Organization, "COVID-19 Weekly Epidemiological Update 22.” 2020. https://www.who.int/docs/defaultsource/coronaviruse/situation-reports/weekly_epidemiological_update_22.pdf. (accessed Jan 20, 2021)

[3] H. Amir, S. Sudarman, A. Asfar, and A. S. Batara, "COVID-19 pandemic: management and global response," J. Kesehat. Lingkung., vol. 12, no. 1, pp. 121-128, 2020, doi: 10.20473/jk1.v12i1si.2020.121-128.

[4] WHO, "Maintaining essential health services: operational guidance for the COVID-19 context." https://www.malecircumcision.org/file/63257/download?token=tqhyhXT3 (accessed Feb 3, 2021)

[5] A. J. Kucharski et al., "Effectiveness of isolation, testing, contact tracing, and physical distancing on reducing transmission of SARS-CoV-2 in different settings: a mathematical modelling study," Lancet Infect. Dis., vol. 20, no. 10, pp. 1151-1160, 2020, doi: 10.1016/S1473-3099(20)30457-6.

[6] S. C. Newbold, D. Finnoff, L. Thunström, M. Ashworth, and J. F. Shogren, "Effects of Physical Distancing to Control COVID-19 on Public Health, the Economy, and the Environment," Environ. Resour. Econ., vol. 76, no. 4, pp. 705-729, 2020, doi: 10.1007/s10640-020-00440-1.

[7] H. Fang, L. Wang, and Y. Yang, "Human mobility restrictions and the spread of the Novel Coronavirus (2019-nCoV) in China," J. Public Econ., vol. 191, p. 104272, 2020, doi: 10.1016/j.jpubeco.2020.104272.

[8] A. Witt, A. Ordóñez, A. Martin, B. Vitiello, and J. M. Fegert, "Child and adolescent mental health service provision and research during the COVID-19 pandemic: Challenges, opportunities, and a call for submissions," Child Adolesc. Psychiatry Ment. Health, vol. 14, no. 1, pp. 8-11, 2020, doi: 10.1186/s13034-020-00324-8.

[9] R. Oktaviany, "The impact of the COVID-19 pandemic on adolescent mental health (In Indonesia: Pengaruh pandemi covid-19 terhadap kesehatan jiwa remaja)," Ilmu Kesehat. Ment. Anak, vol. 2, no. 2, pp. 1-7, 2021.

[10] L. Croll, A. Kurzweil, L. Hasanaj, L. Serrano, and L. J. Balcer, "The psychosocial implications of COVID-19 for a neurology program in a pandemic epicenter Leah," J. Neurol. Sci., vol. 416, p. 117034, 2020

[11] D. Rahmayanthi, M. F. Moeliono, and L. Kendhawati, "Adolescents Mental Health During Covid-19 Pandemic," Insight J. Ilm. Psikol., vol. 23, no. 1, pp. 91-101, 2021.

[12] B. Masyah, "COVID-19 pandemic on mental health and psychosocial (In Indonesia: Pandemi COVID-19 terhadap kesehatan mental dan psikososial)," Mahakan Noursing, vol. 2, no. 8, pp. 353-362, 2020.

[13] I. Yuzulia, "The challenges of online learning during pandemic: students' voice," Wanastra J. Bhs. dan Sastra, vol. 13, no. 1, pp. 08-12, 2021, doi: 10.31294/w.v13i1.9759.

[14] H. Y. Li, H. Cao, D. Y. P. Leung, and Y. W. Mak, "The psychological impacts of a covid-19 outbreak on college students in China: a longitudinal study,” Int. J. Environ. Res. Public Health, vol. 17, no. 11, 2020, doi: 10.3390/ijerph17113933.

[15] K. O'Sullivan et al., "A qualitative study of child and adolescent mental health during the COVID-19 pandemic in Ireland," Int. $J$. Environ. Res. Public Health, vol. 18, no. 3, pp. 1-15, 2021, doi: 10.3390/ijerph18031062.

[16] D. Moher et al., "Preferred reporting items for systematic reviews and meta-analyses: The PRISMA statement," PLoS Med., vol. 6, no. 7, pp. 1-6, 2009, doi: 10.1371/journal.pmed.1000097.

[17] R. Leonardo, "PICO: Model for clinical questions evidence based medicine and practice PICO: model for clinical questions," Evid Based Med Pr., vol. 3, no. 2, pp. 1-2, 2018, doi: 10.4172/2471-9919.1000115.

[18] S. Baird et al., "Social isolation and disrupted privacy: Impacts of COVID-19 on adolescent girls in humanitarian contexts," Girlhood Stud., vol. 13, no. 3, pp. 98-115, 2020, doi: 10.3167/GHS.2020.130308.

[19] J. De Man et al., "Disentangling depression in Belgian higher education students amidst the first COVID-19 lockdown (AprilMay 2020)," Arch. Public Heal., vol. 79, no. 3, pp. 1-10, 2021, doi: 10.1186/s13690-020-00522-y. 
[20] T. Elmer, K. Mepham, and C. Stadtfeld, "Students under lockdown: comparisons of students' social networks and mental health before and during the COVID-19 crisis in Switzerland," PLoS One, vol. 15, no. 7 July, pp. 1-22, 2020, doi: 10.1371/journal.pone.0236337.

[21] C. I. Mallik and R. B. Radwan, "Impact of lockdown due to COVID-19 pandemic in changes of prevalence of predictive psychiatric disorders among children and adolescents in Bangladesh," Asian J. Psychiatr., vol. 56, no. 37, p. 102554, 2021, doi: 10.1016/j.ajp.2021.102554.

[22] S. Munasinghe et al., "The impact of physical distancing policies during the COVID-19 pandemic on health and well-being among Australian adolescents," J. Adolesc. Heal., vol. 67, no. 5, pp. 653-661, 2020, doi: 10.1016/j.jadohealth.2020.08.008.

[23] B. Oosterhoff et al., "Adolescents' motivations to engage in social distancing during the COVID-19 pandemic: associations with mental and social health," J. Adolesc. Heal., vol. 290, no. January, pp. 19-21, 2020.

[24] G. Pietrabissa and S. G. Simpson, "Psychological consequences of social isolation during COVID-19 outbreak," Front. Psychol., vol. 11, no. September, pp. 9-12, 2020, doi: 10.3389/fpsyg.2020.02201.

[25] WHO, "Mental Health and psychosocial considerations during COVID-19 outbreak." 2020 file:///C:/Users/muled/Downloads/COVID referances/Mental health and psychosocial considerations during the.pdf (accessed Feb $13,2021)$

[26] N. Vindegaard and M. E. Benros, "COVID-19 pandemic and mental health consequences: systematic review of the current evidence," Brain. Behav. Immun., vol. 89, pp. 531-542, 2020, doi: 10.1016/j.bbi.2020.05.048.

[27] L. J. Labrague and C. A. Ballad, "Lockdown fatigue among college students during the COVID-19 pandemic: Predictive role of personal resilience, coping behaviors, and health," Perspect. Psychiatr. Care, no. 3, pp. 1-8, 2021, doi: 10.1111/ppc.12765.

[28] C. Phelps and L. L. Sperry, "Children and the COVID-19 pandemic," Psychol. Trauma Theory, Res. Pract. Policy, vol. 12, no. 1, pp. 73-75, 2020, doi: 10.1037/tra0000861.

[29] L. Duan et al., "An investigation of mental health status of children and adolescents in china during the outbreak of COVID-19," J. Affect. Disord., vol. 275, no. December, pp. 112-118, 2020, doi: 10.1016/j.jad.2020.06.029.

[30] M. Barseli, I. Ifdil, and L. Fitria, "Academic stress due to COVID-19 (In Indonesia: Stress akademik akibat COVID-19)," J. Penelit. Guru Indones., vol. 5, no. 2, pp. 95-99, 2020.

[31] A. Kirana and W. Juliartiko, "Self-regulated learning and academic stress during online learning during the COVID-19 Pandemic (In Indonesia: Self-regulated learning dan stres akademik saat pembelajaran daring di masa pandemi COVID-19)," J. Psikol., vol. 14, no. 1, pp. 52-61, 2021.

[32] I. P. A. Apriliana, K. Suranata, and I. K. Dharsana, "Reduce student anxiety through cognitive behavioral counseling, (In Indonesia: Mereduksi kecemasan siswa melalui konseling cognitive behavioral)," Indones. J. Educ. Couns., vol. 3, no. 1, pp. 21-30, 2019, doi: 10.30653/001.201931.46.

[33] A. H. Ade, "Students academic stress and implications in counseling," Students Acad. Stress Implic. Couns. J. Neo Konseling 1.3 (2019)., vol. 1, no. 3, pp. 1-7, 2019, doi: 10.24036/00130kons2019.

[34] N. H. H. Ramli, M. Alavi, S. A. Mehrinezhad, and A. Ahmadi, "Academic stress and self-regulation among university students in Malaysia: mediator role of mindfulness," Behav. Sci. (Basel)., vol. 8, no. 1, pp. 1-9, 2018, doi: 10.3390/bs8010012.

[35] Z. Zaharah, G. I. Kirilova, and A. Windarti, "Impact of corona virus outbreak towards teaching and learning activities in Indonesia," SALAM J. Sos. dan Budaya Syar-i, vol. 7, no. 3, pp. 269-282, 2020, doi: 10.15408/sjsbs.v7i3.15104.

[36] W. Cai, B. Lian, X. Song, T. Hou, G. Deng, and H. Li, "A cross-sectional study on mental health among health care workers during the outbreak of corona virus disease 2019," Asian J. Psychiatr., vol. 51, no. March, p. 102111, 2020, doi: 10.1016/j.ajp.2020.102111.

[37] C. S. de Figueiredo et al., "COVID-19 pandemic impact on children and adolescents' mental health: Biological, environmental, and social factors," Prog. Neuro-Psychopharmacology Biol. Psychiatry, vol. 106, p. 110171, 2021, doi: 10.1016/j.pnpbp.2020.110171.

[38] E. Golberstein, G. Gonzales, and E. Meara, "Coronavirus disease 2019 (COVID-19) and Mental health for children and adolescents," JAMA Pediatr., vol. 174, no. 9, pp. 955-970, 2020, doi: 10.1002/hec.3885.

[39] N. Cuhaci, S. B. Polat, B. Evranos, R. Ersoy, and B. Cakir, "Gynecomastia: clinical evaluation and management," Indian J. Endocrinol. Metab., vol. 18, no. 2, pp. 150-158, 2014, doi: 10.4103/2230-8210.129104.

[40] S. Yaacob, R. Juhari, M. Talib, and I. Uba, "Loneliness, stress, self esteem and depression among Malaysian adolescents Siti Nor Yaacob Rumaya Juhari Mansor Abu Talib Ikechukwu Uba,” J. Kemanus., vol. 14, no. 2002, pp. 85-92, 2009.

[41] J. H. Ruskandi, "Adolescent anxiety during the COVID-19 Pandemic (In Indonesia: Kecemasan remaja pada masa pandemi COVID-19)," J. Penelit. Perawat Prof., vol. 3, no. 3, pp. 483-492, 2021, doi: 10.37287/jppp.v3i3.530.

[42] Y. Fitria, Linda, Neviyarni, Netrawati, \& Karneli, "Cognitive behavior therapy counseling untuk mengatasi anxiety dalam masa pandemi COVID-19," Al-Irsyad J. Pendidik. dan Konseling, vol. 10, no. 1, pp. 23-29, 2020.

[43] Hardiyati, E. Widianti, and T. Hernawaty, "Anxiety during the COVID-19 pandemi (In Indonesia: Kecemasan saat pandemi COVID-19)," J. Kesehat. Manarang, vol. 6, pp. 27-40, 2020.

[44] N. R. Magson, J. Y. A. Freeman, R. M. Rapee, C. E. Richardson, E. L. Oar, and J. Fardouly, "Risk and Protective factors for prospective changes in adolescent mental health during the COVID-19 pandemic,” J. Youth Adolesc., vol. 50, no. 1, pp. 44-57, 2021, doi: 10.1007/s10964-020-01332-9.

[45] D. Azania and Naan, "Spiritual role for student mental health amid the COVID-19 Pandemic (In Indonesia: Peran Spiritual Bagi Kesehatan Mental Mahasiswa Di Tengah Pandemi COVID-19)," Humanistika J. Keislam., vol. 7, no. 1, pp. 26-45, 2021.

[46] M. Hafizurrachman and R. K. Hartono, "Junk food consumption and symptoms of mental health problems: A meta-analysis for public health awareness," Kesmas J. Kesehat. Masy. Nas., vol. 16, no. 1, pp. 1-8, 2021, doi: 10.21109/KESMAS.V16I1.4541.

[47] S. K. Kar et al., "Mental health research in the lower-middle-income countries of Africa and Asia during the COVID-19 pandemic: A scoping review," Neurol. Psychiatry Brain Res., vol. 38, no. July, pp. 54-64, 2020, doi: 10.1016/j.npbr.2020.10.003.

[48] J.-P. David, C.-B. Ana, and L. Carl, "Physical exercise as therapy to fight against the mental and physical consequences of COVID-19 quarantine: Special focus in older people," Prog. Cardiovasc. Dis., vl. 63, no. 3, pp. 386-3888, 2020, 10.1016/j.pcad.2020.03.009.

[49] M. Aqeel, K. H. Shuja, J. Abbas, T. Rehna, and A. Ziapour, "The influence of illness perception, anxiety and depression disorders on students mental health during COVID-19 outbreak in Pakistan: A web-based cross-sectional survey," Research Square, pp. 118, 2020, doi: 10.21203/rs.3.rs-30128/v1

[50] F. A. Yuarta and I. Nurmala, "Improving mental health of adolescents through," Indian J. Forensic Med. Toxicol., vol. 15, no. 2, pp. 2339-2344, 2021. 


\section{BIOGRAPHIES OF AUTHORS}
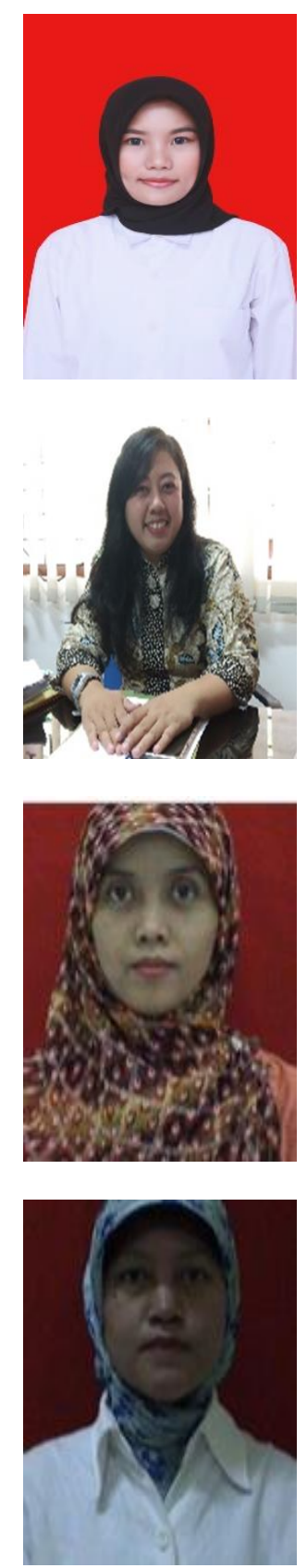

Isma Faridatus Sholihah (D) SII SC P was born in Kediri, April 14, 1997. He earned a bachelor's degree in public health (S.KM) in 2019 from the Universitas Airlangga, Indonesia. Then in 2020, she continued her master's program in public health at the same university until now. Her research focus is on health policy as well as health promotion and behavioral science. She can be contacted at email: ismafs27@gmail.com.

Ira Nurmala (D) 8 SC P is one of the lecturers in health promotion and behavioral science, Universitas Airlangga. She earned her bachelor's degree Public Health (S.KM) from Universitas Airlangga (Indonesia) in 2000. In 2007 earned an M.PH degree from Maastricht University (Netherlands) and in 2014 completed her doctoral education with a Ph.D. at the University of Georgia (USA). She is active in research related to health promotionand behavioral science. She can be contacted at email: iranurmala@fkm.unair.ac.id.

Muji Sulistyowati (D) SC SC is a lecturer at the Faculty of Public Health, Universitas Airlangga (Indonesia). Earned a Bachelor of Public Health (S.KM) in 1996 at Universitas Airlangga (Indonesia), then in 2001 obtained a Masters in Health (M.Kes) from Gajah Mada University and a Doctorate (Dr.) in 2019 from Universitas Airlangga. She is active in research related to health promotion and behavioral science. The focus of research is related to health promotion in adolescents such as the School Health Programs, and the issue of School Health Promotion. She can be contacted by email: muji-s@fkm.unair.ac.id.

Shrimarti Rukmini Devy (iD $\mathrm{SC}$ SC is a senior lecturer at the Faculty of Public Health, Universitas Airlangga (Indonesia). She earned a bachelor's degree (Dra) in 1990 at Universitas Airlangga, then in 2000 earned a master's degree in health (M.Kes) from Gajah Mada University and a Doctoral degree (Dr.) in 2013 from Gajah Mada University as well. She is very active in conducting research and also implementing health empowerment programs in the community. She is active in research related to health promotion and behavioral science. She can be contacted at email: shrimarti-r-d@ fkm.unair.ac.id. 